\title{
VZPOMÍNKA HISTORIKA JOSEFA KLIKA (1896-1965) NA 17. LISTOPAD 1939
}

\author{
ANTONÍN KOSTLÁN - MICHAL V. ŠIMU゚NEK
}

\section{HISTORIAN JOSEF KLIK (1896-1965) AND HIS RECOLLECTION OF 17 NOVEMBER 1939}

This paper offers for the first time the personal recollection of historian Josef Klik, which concerns the events of 17 November 1939. Since he was in touch with several protagonist, it delivers an important inside view.

Keywords: 17 November 1939 - Czech Universities - Second World War

DOI: $10.14712 / 23365730.2020 .4$

\section{Úvodem}

Autorem vzpomínky, v níž se vracíme k bouřlivým událostem před osmdesáti lety, je historik Josef Klik (11. 3. 1896 Deštné, o. Jindřichův Hradec - 10. 5. 1965 Praha). Patřil k významným postavám české historiografie. Máme jej ovšem spojeného spíše s udržováním odkazu Josefa Pekaře (1870-1937), respektive s organizačními proměnami oborové infrastruktury. ${ }^{1}$ Klik začal studovat pražskou filozofickou fakultu v roce 1917 a zdárně ji ukončil řadou zkoušek, jež ho opravňovaly k výuce zejména dějepisu a zeměpisu. Vysokoškolské studium nicméně zakončil až v březnu 1923, kdy dosáhl doktorátu na základě své jediné velké publikované historické práce, věnované národnostnímu vývoji českých zemí. ${ }^{2}$ Podstatnou část svého života pak působil jako středoškolský pedagog (profesor), přičemž jeho učitelská dráha $\mathrm{v}$ době první republiky byla spjata především s reálným gymnáziem na Smíchově, od roku 1937 pojmenovaným po historikovi, spisovateli a překladateli z francouzštiny Jindřichu Vančurovi (1855-1936). Dlouholeté pedagogické působení zúročil v druhé polovině 30. let i při přípravě středoškolských učebnic, a to bud' jako jejich

1 Klikovy životní osudy i odborný přínos naposledy koncízně shrnul Bohumil JiRoušEK, Josef Klik. Historik ve stínu Josefa Pekaře, České Budějovice 2011; tam je na s. 7-9 k dispozici také přehled dosavadní literatury o Klikovi a přehled archivních pramenů, týkajících se jeho života a díla. S ohledem na archivnictví přehledově Jaroslava Hoffmannová - Jana PražÁková (edd.), Biografický slovník archivárù českých zemí, Praha 2000, s. 314.

2 Josef KLIK, Národnostní poměry v Čechách od válek husitských do bitvy bělohorské, Český časopis historický (dále ČČH) 27, 1921, s. 8-62, 28, 1922, s. 31-73; pod stejným názvem vydal otisk díla Historický klub v samostatné publikaci (Praha 1922). 
autor nebo jako redaktor učebnice Pekařovy. ${ }^{3}$ Klikovy vyučovací zkušenosti byly všeobecně uznávány a nepřekvapuje, že to byl právě on, kdo byl pověřen, aby na Prvním sjezdu československých historiků $v$ roce 1937 shrnul nutné změny při přípravě budoucích středoškolských profesorů historie. ${ }^{4}$

Všeobecná známost a autorita, jíž se Klikovi dostávalo v historické obci, se ovšem vázala především $\mathrm{k}$ jeho funkci jednatele Historického klubu (dále jen HK). ${ }^{5}$ Tu vykonával od roku 1925 a o deset let později (1935) k ní přibyla i funkce člena výboru a jednatele Československé historické společnosti. Toto angažmá rozhodně nebylo pro Klika formální záležitostí, protože se pojilo s řadou dosti obtížných organizačních úkolů. Jako jednatel HK měl na starosti plynulý průběh poměrně rozsáhlé vydavatelské činnosti tohoto spolku, která kromě vydávání Českého časopisu historického (ČČH) zahrnovala v průměru až šest dalších publikací ročně. K tomu přistupovalo i rozsáhlé pravidelné psaní zpráv pro časopis i péče o rozsáhlé bibliografické aktivity HK, na nichž se podílel jako autor i jako supervizor. V roce 1935 byl Pekařem přibrán - společně s Josefem Šustou (1874-1945) a Františkem Hrubým (1887-1943) - mezi redaktory ČČH. Po Pekařově smrti v roce 1937 zaručovala trojice Šusta - Hrubý - Klik i nadále vysokou úroveň tohoto ústředního oborového periodika. ${ }^{6}$

Klikovy organizátorské schopnosti při pořádání reprezentativních akcí se projevily již v dubnu 1929, kdy se společně s historikem hospodářských dějin Bedřichem Mendlem (1892-1940) podílel na př́pravě historické sekce Sjezdu československých profesorů filosofie, filologie a historie. Znovu se potvrdily při prípravě Prvního sjezdu československých historiků v květnu 1937.7 Jako organizátor stál na počátku roku 1939 rovněž v pozadí přednáškového cyklu HK Tisíc let národního českého vědomí, v jehož rámci sám přednesl 10. března 1939 výklad o národním vědomí od nástupu Habsburků do bitvy bělohorské. Vpád německých vojsk o pět dnů později pokračování cyklu přerušilo, a tak mj. odpadla i chystaná přednáška Josefa Matouška (1906-1939). ${ }^{8}$

Za nově nastalých poměrů se Klik jako mnozí další čeští intelektuálové musel rozhodovat, do jaké míry své vlastenecké snahy a postoje přizpůsobovat nově vzniklým poměrům. Když jej ministr školství a národní osvěty a profesní kolega Jan Kapras (1880-1947) o prázdninách 1939 vyzval, aby se po emigrovavším Otakaru Odložilíkovi (1899-1973) ujal funkce místopředsedy Historické sekce Kulturní rady (ta původně pracovala při Národní radě české a tou dobou se už modifikovala do ústředí pro kulturní a školskou práci Národního souručenství), Klik funkci přijal a vykonával ji až do svého zhroucení v listopadu 1939.

3 K tomu viz B. JiroušEK, Josef Klik, s. 79-83.

4 Josef KLIK, Vysoká škola a potřeby kandidátů profesury, in: František Kutnar (ed.), První sjezd československých historiků 1937. Přednášky a debaty, Praha 1938, s. 75-80.

5 K dějinám HK viz Karel KuČERA, Historický spolek a Historický klub, ČČH 88/1-2, 1990, s. 85-91; dále také Jiří LACH, Josef Šusta, Jaroslav Werstadt a Historický klub: poznámky nejen výroční, Zpravodaj Historického klubu 16/2, 2005, s. 37-48; Bohumil JiROuŠEK, Historický klub v letech 1945-1955, in: Blanka Zilynská - Petr Svobodný (edd.), Věda v Československu v letech 1945-1953. Sborník z konference, Praha 1999, s. 417-423; TÝž, Historický klub a Josef Klik, ČČCH 97/3, 1999, s. 567-581; Josef KLIK, Josef Pekař a Historický Klub, ČC̆H 43/2, 1937, s. 253-260.

6 B. JiROuŠEK, Josef Klik, s. 71-83.

$7 \mathrm{~K}$ tomu srov. Antonín KostLán, Druhý sjezd československých historiků (5.-11. řijna 1947) a jeho misto ve vývoji českého déjepisectví v letech 1935-1948, Praha 1993, s. 12-15 a 37-47.

8 Státní okresní archiv (SOkA) Jindřichův Hradec, fond Josef Klik, kart. 1, Obhajoba proti nařčení z kolaborace s Němci 1940-1946, s. 4; Josef KLIK, in: ČČH 47, 1946, s. 341; B. JiroušEK, Josef Klik, s. 45. 
Využil však této funkce, aby ve spolupráci s historikem J. Matouškem a etnografem Karlem Chotkem (1881-1967) rozvinul akci na obnovování národních krojů a odbornou péči o ně; souběžně s tím byl iniciován i soupis lidových zvyků. ${ }^{9}$

Tyto aktivity představovaly rámec Klikovy odborné činnosti v historickém okamžiku, k němuž se vztahuje jeho vzpomínka na 17. listopad 1939, jež je zde poprvé uveřejněna. Toto datum, jak je obecně známo, získalo v českých/československých dějinách 20. století mnohonásobnou historickou symboliku. Během „krvavého listopadu“ 1939 došlo nejen k zásadnímu zlomu v chápání reality německé okupace. Byli masově a brutálně perzekvováni univerzitní i jiní vysokoškolští studenti na území protektorátu Čechy a Morava a došlo i k dlouhodobému uzavření českých univerzit a vysokých škol, a tím i převážnému podvázání odborné a vědecké činnosti jako takové. ${ }^{10}$ Ba co víc - 17. listopad 1939 byl nejzazším datem, při němž si česká veřejnost musela přiznat, že veřejné protesty a vyjadřování nespokojenosti, jak na ně byla navyklá ze svého předchozího demokratického vývoje, nemohou podstatně ovlivnit daný stav věcí, ale se vší pravděpodobností přispějí spíše k eskalaci násilí a teroru. ${ }^{11}$

Výmluvným a tragickým důkazem pro tuto skutečnost byla smrt deseti studentů či osob těsně spjatých se studentským prostředím, s nimiž se toto datum neodmyslitelně pojí - totiž Jana Opletala (1915-1939), postřeleného při protestech 28. ř́ijna 1938, jehož pohřeb se stal nacistické moci záminkou k jejímu tvrdému úderu 17. listopadu 1939, a devíti představitelů studentského života, popravených toho dne v ruzyňských kasárnách. Klik se přitom se třemi z nich znal osobně, konkrétně s již zmiňovanými J. Opletalem, J. Matouškem a Janem Weinertem (1914-1939); právě k nim se obrací hlavní část jeho vzpomínky. Přitom ovšem zachycuje i řadu jiných lidských osudů a událostí tohoto vypjatého období.

Pokud jde o společné pojítko mezi Opletalem a Klikem, to představovala Hlávkova studentská kolej, sídlící na rohu Jenštejnské a Dittrichovy ulice na Novém Městě v Praze. ${ }^{12}$ Jejím výhodám se totiž oba dva těšili, i když každý v různé době; Klik byl do ní přijat v září 1918. ${ }^{13}$ Nejdříve jako její ,,chovanci“, aby se na sklonku 30. let na její půdě potkávali coby funkcionáŕi jejích orgánů. Osudy této koleje na prahu druhé světové války jsou př́mo leitmotivem předkládané Klikovy vzpomínky.

9 SOkA Jindřichův Hradec, f. Josef Klik, kart. 1, Obhajoba, s. 6-7; České národní kroje oživají, Národní listy 79/281, 1939, 15. 10., s. 2.

10 Pro zlom v chápání reality okupace současníky vzpomínkově např. Ladislav K. FEIERABEND, Politické vzpomínky, I, Brno 1994, s. 234-241.

11 Z dosti rozsáhlé literatury k problematice 17. listopadu 1939 lze výběrově uvést zejm. František KRoPÁč - Vlastimil Louda, Persekuce českého studentstva za okupace. 28. řjjen 1939. Německý útok na české vysokoškoláky. Uzavření českých vysokých škol, Praha 1945; Bohdan Rossa (ed.), Sedmnáctý listopad. Přrispěvek k historii perzekuce české mládeže za okupace, Praha 1959; František BuriánEK (ed.), Svědectví. Přiběhy českých studentů z akce 17. listopad, Praha 1984; Jozef LeIkert, Ráno přišla noc, Praha 1989; Tomáš PasÁk, 17. listopad 1939 a Univerzita Karlova, Praha 1997; Jozef LeIKert, Černý pátek sedmnáctého listopadu, Praha 2001; Zdeněk Pousta (ed.), Trpké vzpominky na 17. listopad 1939, Praha 2014; Jozef LeIKERT, Uloupené mládí. Utrpení studentů z akce 17. listopad 1939 v koncentračním táboře Sachsenhausen, Praha 2019 (př́nos této knihy je bohužel oslaben některými nepodloženými hypotézami, viz např. s. 12-13). Další literaturu k tomuto tématu shrnuje Z. Pousta, Trpké vzpomínky, s. 16, pozn. 6.

12 Jako archivní fond této důležité instituce bohužel existuje pouze nepatrné torzo uložené v Archivu hlavního města Prahy (AMP), f. Hlávkova studentská kolej českých vysokých škol pražských (1904-1945), a v Archivu Univerzity Karlovy (AUK) v Praze, f. Všestudentský archiv, v němž jsou dochovány zápisy ze schůzí výboru.

13 Srov. Hlávkovy studentské koleje českých vysokých škol pražských, Národní politika 36/221, 1918, 26. 9., s. 4. Dále srov. B. JiRoušEK, Josef Klik, s. 23. 
Hlávkova kolej byla nejenom velkoryse pojatým ubytovacím zařízením pro více než 200 studentů, které bylo z popudu a s finanční podporou architekta a významného českého mecenáše Josefa Hlávky (1831-1908) vybudováno a v roce 1904 otevřeno přímo v městském centru, ale zároveň i ústavem, který provoz tohoto ubytovacího zařízení zajišstoval hospodářsky i finančně. Její samospráva podle ustálených kritérií vybírala na každý semestr studenty, kteří tu pak směli bydlet a kterým se mohly vyplácet př́padné podpory. Ubytování v Hlávkově koleji bylo určeno pro české (a další slovanské) studenty pražských vysokých škol s českým vyučovacím jazykem (tedy především pro českou Karlo-Ferdinandovu univerzitu, tj. v období první republiky Karlovu univerzitu, a pro České vysoké učení technické). Mezi další kritéria uplatňovaná obvykle při výběru chovanců patřila nemajetnost, složení maturity s vyznamenáním a mimořádné studijní výsledky na vysoké škole. Studenti vybraní k ubytování se zavazovali kromě dodržování ubytovacích pravidel také ke studiu vybraného cizího jazyka, jakož i k pěstování šermu. ${ }^{14}$ Za to se jim dostávalo zdarma nebo za nevysoké poplatky ubytování na dvou či jednolůžkových pokojích, možnosti využívání společných prostor, zařízení (včetně knihovny a čítárny) a služeb (včetně praní prádla), třrikrát denně jídlo (snídaně, oběd a chléb) a často i menší finanční stipendium. ${ }^{15}$

Činnost tohoto ústavu byla zajišt'ována poměrně složitou organizační strukturou, které vtiskl základní podobu sám Hlávka a která se nicméně v průběhu doby poněkud pozměňovala. Budovu koleje i dění v ní ovládal spolek nazvaný „Hlávkovy studentské koleje českých vysokých škol pražských“. ${ }^{16} \mathrm{~V}$ čele spolku stálo kuratorium, jehož předsedou byl pravidelně pražský primátor. Role kuratoria byla však povýtce jen reprezentační, protože vlastní starost o provoz kolejí spadala na správní výbor. V druhé polovině 30. let měl tento výbor 15 členů, mezi nimiž měli tou dobou rozhodující postavení bývalí kolejní chovanci. ${ }^{17}$ Vlastní provoz měl pak na starosti ústavní ředitel, který v budově rovněž přímo bydlel.

Podle původně stanovených pravidel sami studenti ubytovaní na koleji do jejího provozu neměli zasahovat, časem se však z jejich strany ustavila samospráva, která si osobovala právo vyjadřovat se k řadě otázek, jež studenti považovali za důležité. Byl to právě Klik, jenž si v době svých studií jako první předseda studentské samosprávy dokázal prosadit pravidelné přizvávání na schůze správního výboru, a to konkrétně od května 1922. Přitom se osvědčil natolik, že se zanedlouho po skončení studií stal řádným členem správního

14 V př́ípadě J. Klika bylo vysvědčení o absolvování šermířského výcviku s velmi dobrým prospěchem vystaveno 30. 3. 1919 - viz Archiv Národního muzea (ANM) Praha, f. Klik, kart. 1, i. č. 3, Vysvědčení Hlávkovy studentské koleje, 1918-1919.

15 Srov. Josef HorčičKa, Dvacet let Hlávkových studentských kolejí českých vysokých škol pražských, Praha 1925 (původně vyšlo pod názvem Dvacet let významné sociálni instituce pro studentstvo, in: Péče o studentstvo 2/9-10, 1924, s. 143-155); Jiří PoкоRnÝ, Odkaz Josefa Hlávky. Historie České akademie věd a umění, Hlávkových studentských kolejí, Nadání Josefa, Marie a Zděnky Hlávkových, jakož i Národohospodářského ústavu, Praha 2008, s. 94-158. Ve srovnání s dalšími dobovými donátory pak Kristýna VRBovÁ, Podoby mecenášství v českém prostredi, Praha 2018 (diplomová práce KTF UK Praha).

16 Srov. Josef JírA, Hlávkova studentská kolej českých vysokých škol. Osudy lidí a budov vobdobí od založení do konce II. světové války, in: Josef Hlávka. Jeho myšlenkový odkaz a 100 let činnosti jeho nadace, Praha 2004, s. 128-137.

17 Viz výroční zprávy spolku z této doby: XXXV. výroční zpráva spolku „Hlávkovy studentské koleje českých vysokých škol pražských" v Praze II., Jenštejnská In., za správní rok 1935-36, Praha 1937; XXXVI. výročni zpráva spolku „Hlávkovy studentské koleje českých vysokých škol pražských“ v Praze II., Jenštejnská In., za správní rok 1936-37, Praha 1937; XXXVII. výroční zpráva spolku „Hlávkovy studentské koleje českých vysokých škol pražských“ v Praze II, Jenštejnská In, za správní rok 1937-38, Praha 1939. V těchto publikacích rovněž blíže k organizační struktuře spolku. 
výboru a v jeho rámci byl ustaven jedním z referentů pro přijímání nových chovanců. ${ }^{18}$ Jisté změny v roli, kterou Klik hrál ve vedení Hlávkovy koleje, nastaly v druhé polovině 30. let. Členem Správního výboru byl ještě pro období 1935-1936, ${ }^{19}$ avšak když v březnu 1936 zemřel dlouholetý správce a posléze ředitel Hlávkových kolejí (Antonín Fiala), ${ }^{20}$ uvolil se Klik príijmout funkci ústavního ředitele; ve zřejmé souvislosti s tím pak odstoupil na valné hromadě 14 . května 1936 ze správního výboru. ${ }^{21}$

Tuto ředitelskou funkci zodpovědně vykonával a využíval ji mj. pro publicitu kolejí v tisku a v rozhlase. Zajištování každodenního provozu koleje se však zřejmě značně kř́žilo s jeho dalšími povinnostmi. V létě 1937 se tak ,žrekl mista ústavního ředitele kolejí, rozhodnuv se věnovati činnosti vědecké a pedagogické“".22 Ředitelskou funkci po něm na základě výběrového řízení převzal od 1. ledna 1938 Ing. Václav Weiser (1896-1963).23 $\mathrm{V}$ důsledku úmrtí dlouholetého člena Správního výboru, docenta vodního hospodářství na ČVUT Josefa Vrby (1889-1938), byl pak J. Klik kooptován na jeho místo, čímž se vrátil i k agendě, kterou ve Správním výboru předtím dlouhodobě zajišstoval. ${ }^{24}$

Souběžně se svým působením v Hlávkových kolejích byl ovšem Klik rovněž funkcionářem $\mathrm{v}$ dalších významných celopražských organizacích, jejichž prostřednictvím se studentům dostávalo sociální podpory. Vykonával funkci předsedy podpůrného odboru Sboru sociální péče o vysokoškolské studentstvo ${ }^{25}$ a dále byl také členem výboru Studentského zdravotního ústavu v Praze. ${ }^{26}$

$18 \mathrm{~K}$ tomu srov. XXXVII. výroční zpráva, s. 6-7; Josef KLIK, Z let poválečných, in: Alois Jokl - Josef Klik - František Roubík (edd.), Hlávkovy studentské koleje. Vzpomínky, Praha 1934, s. 91-94; TÝž, Z praxe přijímajícího referenta, tamtéž, s. 108-112.

$19 X X X V$. výroční zpráva, s. 9.

20 Úmrtí ředitele Hlávkových kolejí, in: Národní listy 76/84, 1936, Večerník 25. 3., s. 2.

$21 X X X V$. výroční zpráva, s. 16.

22 XXXVI. výroční zpráva, s. 26.

23 Václav Weiser se narodil ve Zbýšově u Kutné Hory, kde jeho otec působil jako řídící učitel. Po absolvování střední školy pokračoval ve studiu na ČVUT a během vysokoškolských studií byl chovancem Hlávkovy koleje. Později působil jako revizní inspektor Úrazové pojišt'ovny dělnické pro Čechy v Praze. Po J. Klikovi se stal ředitelem Hlávkovy koleje. Z titulu této funkce byl spolu se studenty Hlávkovy koleje 17. listopadu 1939 zatčen, ale byl propuštěn. Poté se mu podařilo uprchnout do Velké Británie, kde vstoupil do služeb československé exilové vlády a působil jako pracovník Nejvyššího kontrolního úřadu. Po skončení druhé světové války působil jako státní úředník v Praze, kde také zemřel.

24 K vazbě ČVUT na Hlávkovu nadaci srov. Magdalena TAYERLovÁ, Hlávkova nadace a ČVUT, Acta polytecnica, ř. 6 , č. 4, 1990, s. 101-106.

25 Sbor sociální péče o vysokoškolské studentstvo v Praze po své reorganizaci v letech 1928-1944 existoval na spolkové bázi a sídlil po většinu své existence ve Strakově akademii. Byl poradním sborem Ministerstva školství a národní osvěty a zároveň i ústřední sociální studentskou institucí. Vedle analytických, evidenčních a statistických úkolů se soustřed’oval na podporu jak studentských spolků a organizací, tak i jednotlivců, kterým např. poskytoval státní stipendia, bezúročné půjčky, tramvajenky, slevy na kulturní akce, pro nemajetné i ošacování. Viz AMP Praha, f. MHMP II., Národní výbor hl. m. Prahy, odbor vnitřních věcí, spolkový katastr, sign. II/0803. Dále srov. Středisko studentské sociální péče, Národní listy 75/242, 1935, 3. 9., s. 4. Klik se jako předseda Podpůrného odboru tohoto sboru snažil mimo jiné v roce 1937 zvýšit finance využitelné na podporu studentů i prosazováním loterie v jejich prospěch. K tomu viz Dobročinná loterie ve prospěch čsl. studentstva, Národní listy 77/154, 1937, 6. 6., s. 4.

26 Studentský zdravotní ústav v Praze (původně Zdravotní ústav pro studentskou sociální péči zdravotní) existoval v letech 1921-1950 na spolkové bázi a zpočátku ve Strakově akademii. Jeho původním účelem byla prevence tuberkulózy a venerických chorob mezi studujícími, postupně se však zejména s podporou Univerzity Karlovy proměnil ve významnou zdravotní instituci zajišt’ující léčbu a zdravotnickou prevenci (včetně letních táborů a lázeňské péče) pro značnou část studujících na českých vysokých školách v Praze. V jeho kuratoriu zasedali zástupci vysokých škol i studentů, ministerští úředníci i zdravotničtí odborníci. K jeho činnosti viz 
Na sklonku 30. let byli na schůze správního výboru spolku Hlávkových kolejí pravidelně přizváváni také dva zástupci studentské samosprávy. ${ }^{27}$ Od podzimu 1938 těmito dvěma zástupci byli předseda Ústředního sboru samosprávy chovanců Hlávkových studentských kolejí českých vysokých škol pražských, student medicíny Maxmilian Martischnig (1912-1984) a místopředseda tohoto sboru Jan Opletal. ${ }^{28}$ Ten působil zároveň jako sociální referent, což znamená, že se staral o sociální pomoc studentům a měl poradní hlas při navrhování stipendií. ${ }^{29}$ Jako takový přicházel do častého styku právě s Klikem, který obdobnou agendu zajišt’oval za Správní výbor.

Opletal byl absolventem osmiletého zemského reálného gymnázia v Litovli (škola dnes nese jeho jméno).$^{30}$ Maturoval zde s vyznamenáním v červnu 1934 a poté se pokoušel o vojenskou dráhu. Lékařskou fakultu UK začal studovat v zimním semestru akademického roku 1936/37. Hned od počátku svého studia byl ubytován v Hlávkově koleji, což bylo - jak na to poukazují někteří historici - dost neobvyklé. ${ }^{31}$ Právě Klikova vzpomínka nám tuto věc poněkud ozřejmuje, nebot' dává jeho přednostní ubytování do souvislosti $\mathrm{s}$ intervencí ředitele litovelského reálného gymnázia. Ten totiž obvykle doporučoval, $\mathrm{v}$ čí prospěch může být využito „záložené místo“ (tedy doplňkové finanční stipendium), jež bylo určeno právě pro nadané litovelské absolventy. Zpráva o činnosti Hlávkových kolejí pro školní rok 1937/38 uvádí Opletala dokonce jako držitele hned dvou litovelských stipendií (tedy „založených míst“): První bylo Jubilejní místo ku podpoře nemajetných studujících reálného gymnázia $\mathrm{v}$ Litovli a druhé Založené ,jubilejní “ místo města Litovle. ${ }^{32}$ Je zřejmé, že Opletal získal během svých gymnaziálních studií v Litovli dobré renomé, což nám ostatně potvrzuje i výčet tamních pedagogů a intelektuálů, kteří mu byli ochotni při jeho studiu prátelsky pomoci radou či materiálně. 33

Pravidelná spolupráce obou mužů dovolila Klikovi, aby nám po letech podal zpětnou charakteristiku Opletala jakožto mladého seriózního a svědomitého člověka, s výrazně rozvinutým smyslem pro sociální spravedlnost. Vzhledem $\mathrm{k}$ tomu, že vzpomínka byla zaznamenána v posledních letech Klikova života, respektive někdy mezi lety 1961-1965, tzn. více než dvacet let po popisovaných událostech, nabízí nám i jistý důkaz o korekci vlastních vzpomínek ve prospěch legendy, jež byla o Opletalovi rozvíjena komunistickým režimem.

např. Deset let práce Studentského zdravotniho ústavu v Praze 1921-1931, Praha 1931; Šestnáct let práce Studentského zdravotního ústavu v Praze, Národní politika 55/90, 1937, 1. 4., s. 7.

$27 \mathrm{~K}$ tomu srov. XXXVII. výroční zpráva, s. 20.

28 T. PASÁK, 17. listopad 1939, s. 62.

29 Tamtéž.

30 K životu J. Opletala zejména T. PASÁK, 17. listopad 1939, s. 59-68; J. LeIKERT, Černý pátek, s. 45-84; Zdeněk Vyhlídal, Jan Opletal - osudný podzim 1939, Praha 2007; Marie TurkovÁ, Jan Opletal. Známý či neznámý hrdina, Olomouc 2011; Jana BARTošovÁ, Nesmíme zapomenout: Jan Opletal a další oběti listopadu 1939. Nacistická perzekuce českých studentủ během 2. světové války, Praha 2015. Do okruhu literatury faktu patří kniha Zdeňka Vyhlídala, Kdybych tě volal, už se neotáčej. Př́iběh Jana Opletala, Praha 2015.

31 Srov. T. PASÁK, 17. listopad 1939, s. 61; Marek DuUČAnSKÝ, Jaký byl Jan Opletal?, iForum. Online magazín Univerzity Karlovy, 11. 11. 2009, dostupné na <https://iforum.cuni.cz/IFORUM-8120.html >, ověřeno 5. 2. 2020.

$32 \mathrm{~K}$ tomu viz XXXVII. výroční zpráva, s. 30-31. Prvně zmiňované záložní místo využíval Opletal v letním semestru, druhé pak v obou semestrech. Držení více „záložních míst“ najednou stejnou osobou bylo obvyklé i v jiných př́padech. Srov. Jindřich BEnda, Hlávkova studentská kolej - počátek mé dospělosti, in: Sborník vzpomínek bývalých studentů Hlávkovy koleje, Praha 1996, s. 9-12, zde s. 11.

33 Viz Bohumil VAŇÁK, Jan Opletal a 17. listopad, Litovel 1979. K Opletalově studijní vytrvalosti a úrovni viz obdivnou vzpomínku Jaroslava KosA, Vzpominky na život v Hlávkových kolejich českých vysokých škol v Praze, Jenštejnská ul. 1, in: Sborník vzpomínek, s. 32-35, zde s. 33. 
Klik mj. uvádí: „V koleji byl pokládán za sociálního demokrata; teprve asi 1961 jsem zvěděl od profesora Sosny, že tam pracoval v komunistické skupině. “34 O tom, že Opletal byl levicově založený, přitom není pochyb, nebot' právě tento fakt ho zřejmě vynesl i do funkce místopředsedy studentské samosprávy Hlávkovy koleje, nebot' mezi studenty byla tou dobou respektována potřeba rovnováhy mezi pravicí a levicí ve vedení Ústředního sboru. ${ }^{35}$ Víme, že již z rodiny inklinoval k sociálně demokratickému vidění světa, ${ }^{36}$ avšak např. při svém pokusu o armádní kariéru se dokázal zřejmě dosti pragmaticky přizpůsobit vstupem do Republikánského dorostu. ${ }^{37}$ Tvrzení o jeho součinnosti s komunistickou organizací v koleji je však založeno pouze na svědectví krajně nespolehlivého informátora, Františka Sosny (1913-1998). ${ }^{38}$ Ten je v roce 1963 i publikoval ve stati, která se vyznačuje hrubými věcnými chybami a zjevnou tendenčností. Jen na okraj v této souvislosti např. připomeňme, že podle Sosnova tvrzení byl i Opletalův pražský pohřeb připravován výhradně komunistickými studenty. ${ }^{39}$

Druhou osobností, které je Klikova vzpomínka věnována, je další výrazná postava na historiografickém poli druhé poloviny třicátých let, Šustův žák Josef Matoušek (1906-1939). Tento mladý historik si dokázal zjednat velké renomé pracemi z českých politických dějin 19. století a svůj odborný zájem postupně rozšiřoval i na problematiku vývoje národního uvědomování a sjednocovacích hnutí v jiných zemích, zejména v Itálii. Byl dobrým znalcem italského vývoje a neskrýval své jisté sympatie k tamnímu fašistickému hnutí. ${ }^{40}$ Vedle Filozofické fakulty UK byl též absolventem Státní archivní školy, což mu od roku 1931 zajistilo místo v Českém zemském archivu v Praze. Účastnil se rovněž meziválečného archivního výzkumu ve Vatikánu, kde se zapojil do projektu zpřístupňování diplomatických zpráv papežských nunciů působících v Praze v rudolfinském období. To ho mj. dovedlo ke studování evropské raně novověké protireformace, jejíž vývoj pak přehledně shrnul v Dějinách lidstva, redigovaných J. Šustou. ${ }^{41}$ Zabýval se i samotnou postavou

34 Viz edici zde v př́loze.

35 Srov. vzpomínky Josefa ŠÁrky, 17. listopad znamená, nebát se, in: Sborník vzpomínek, s. 59-63.

36 To shrnuje T. PASÁk, 17. listopad 1939, s. 60.

37 Josef Šárka na to vzpomíná takto: „Překvapil mne, když mi řekl, že byl členem Republikánského dorostu jako já, ale že v dané době nezáleží, jestli jsme na pravici či levici, že musíme táhnout proti Ř́iši. “ Srov. J. Š́́RKA, 17. listopad znamená, nebát se, s. 60. K Opletalově vojenské dráze srov. Jiří PlachÝ, Voják Jan Opletal, Historie a vojenství 59/1, 2010, s. 151.

38 František Sosna (1913-1998) byl chovancem Hlávkovy koleje jako student FF UK ve stejné době jako J. Opletal. Po válce Sosna působil na středních školách a později jako lektor jazyků na Vysoké škole pedagogické v Praze a od roku 1959 na katedře jazyků FF UK. K jeho podílu na „normalizaci“ FF UK po roce 1969 viz Josef Petráñ, Filozofové dělaji revoluci. Filozofická fakulta Univerzity Karlovy během komunistického experimentu (1948-1968-1989), Praha 2015, s. 434-435, 447-448; Jakub JAREŠ - Matěj SPURnÝ - Katka VolnÁ a kol., $S$ minulostí zúčtujeme. Sebereflexe Filozofické fakulty UKv dokumentech sedmdesátých a devadesátých let 20. století, Praha 2014, s. 223-224, 418-420 aj. K jeho roli tajného spolupracovníka StB (krycí jméno Nývlt) a držitele propůjčeného bytu viz Archiv bezpečnostních složek (ABS) Praha, operativní svazek centrálních útvarů MV a KS MV Praha, i. j. 744307. Ke komunistickému studentskému hnutí v meziválečném období tendenčně Ivo TesÁR, Komunistické studentské hnutí na pražských vysokých školách v předmnichovské republice, AUC-HUCP 3/1, 1962, s. 5-82.

39 František Sosna, Hlávkova kolej, lidé a události kolem, in: Jaroslav Kladiva (ed.), Za lepší svět. Sborník statí a vzpomínek na studentské pokrokové hnutí třicátých let, Praha 1963, s. 251-262.

40 Viz např. jm (= Josef Matoušek), Mussolini Benito, in: Ottův slovník naučný nové doby, díl IV/1, Praha 1936, s. 392-393.

41 Josef Matoušex, Katolická reformace a zápas o západní Evropu, in: Josef Šusta (ed.), Dějiny lidstva od pravěku k dnešku, V, Praha 1938, s. 369-438. 
císaře Rudolfa II. a jeho práce o turecké válce v evropské politice v letech 1592-1594 mu zajistila docenturu na jeho alma mater, takže od roku 1935 se věnoval rovněž výuce. ${ }^{42}$

Na sklonku 30. let však Matoušek velmi výrazně zasahoval - po vzoru svého otce, poslance a ministra - rovněž do české politiky a politické publicistiky, a to způsobem, který z mnoha zorných úhlů mohl vzbuzovat (a také ve skutečnosti vzbuzoval) značnou kritiku. Jako velký stoupenec prvního československého premiéra Karla Kramáře (1860-1937) podrobil v období druhé republiky zdrcující kritice Benešovu zahraniční politiku a před 15. březnem 1939 prosazoval proněmeckou a proitalskou orientaci zbytkového Česko-Slovenska. Záhy po vytvoření protektorátu Čechy a Morava byl státním prezidentem dr. Emilem Háchou (1872-1945) jmenován členem Výboru Národního souručenství (byl i členem jeho četných výborů a komisí; NS) a místopředsedou Českého svazu pro spolupráci s Němci (ČSSN). Do těchto pozic však tuto nesporně kontroverzní postavu českých dějin nehnala oportunistická kolaborantská touha po rychlé kariéře, ale přesvědčení, že s jejich prrijetím bude moci spíše napomáhat obraně a rozvoji českých národních zájmů na politickém, hospodářském i kulturním poli. ${ }^{43}$ Podílel se na řadě akcí směřujících k ochraně českých národních tradic, přičemž na některých z nich spolupracoval mj. právě s J. Klikem, jak již bylo výše připomenuto. Jako vyhraněný český nacionalista hájil myšlenku rovnoprávnosti českého a německého národa. Jak např. napsal v novinovém úvodníku z 8. srpna 1939: „Pro každého Čecha podmínkou skutečné spolupráce, již si upřimně přejeme, je rovnost životních podmínek Němců v Protektorátě a Čechů v Sudetách."44 Narážel tím ovšem stále silněji na praktickou a každodenní nadřazenost Němců nad Čechy, jak ji nastolovala jako conditio sine qua non protektorátních poměrů nacistická moc.

Po Opletalově pohřbu chtěl Matoušek společně s delegací Národního svazu českého studenstva v Čechách a na Moravě intervenovat ve prospěch zatčených studentů u Háchy; audience se měla konat právě 17 . listopadu, ale za daného vývoje událostí k ní již nedošlo. ${ }^{45}$ Na Klikově vzpomínce zaujme především okolnost, jakými křivolakými cestami se redaktor ČČH dobíral zjištění, že právě tento jeho přítel a tou dobou už uznávaný historik byl jednou z devíti obětí, jejichž popravu oznámila vyhláška říšského protektora publikovaná 17. listopadu 1939. Je ostatně známo i odjinud, že první informace o jménech popravených se šířila doma i v zahraničí různými neoficiálními kanály, protože nebyla oficiálně

42 Viz Josef MatoušEK, Turecká válka v evropské politice v letech 1492-1594. Obraz z dějin diplomacie protireformační, Praha 1935 (= Rozpravy ČAVU, tř́ída I, č. 82). K Matouškově odborné kariéře a jeho dílumm viz Jan KLEPL, Neshášejte oheñ ducha! (K osmému výroči smrti hořického rodáka doc. dr. Josefa Matouška), Pod Zvičinou 2/2, 17. 10. 1947, s. 17-21 (tato stat' byla společně se vzpomínkou M. Matouškové opětně otištěna v publikaci Památce hořického rodáka doc. Josefa Matouška, Hořice 1947); František KutNar, Přehledné dějiny českého dějepisectví, II, Praha 1978, s. 331-332; Marie ŠTemberkovÁ, Josef Matoušek, Zpravodaj Historického klubu 17/1, 2006, s. 36-46.

43 K tomu viz např. Josef MATOUšEK, Ne politikaření, ale politiku, Národní listy 78/202, 1939, 28. 7., s. 1.

44 Citát viz Josef MatoušEK, Vlast půdy a vlast duší, Národní listy 79/213, 1939, 8. 8., s. 1. K Matouškovým politickým postojům srov. T. PASÁK, 17. listopad 1939, s. 102-105; Jarmila PešKovÁ, Josef Matoušek: zapomenutá obět' 17. listopadu, Dějiny a současnost 21/6, 1999, s. 37-41; TÁž, Doc. PhDr. Josef Matoušek: základní nárys politické činnosti, in: Pavel Marek (ed.), Osobnost v politické straně. Sborník referátů z konference „Úloha osobností v dějinách politických stran na území českých zemí a Československa v letech 1861-1999“, Olomouc 19. - 20. ř́inna 1999, Olomouc 2000, s. 309-316; Josef Tomeš, Devět zapomenutých, in: Jaroslav Havel (ed.), Odkaz 17. listopadu po šedesáti letech. Pamětní sborník, Praha 2000, s. 20-31.

45 K audienci u Háchy viz T. PASÁK, 17. listopad 1939, s. 82. 
publikována. ${ }^{46} \mathrm{~V}$ tom se praxe okupačních orgánů v prvním období existence protektorátu výrazně lišila od doby teroru po útoku na R. Heydricha v květnu 1942, kdy halasné zveřejňování jmen řady popravených probíhalo podle předem připraveného schématu a mělo přispívat k psychologickému zastrašování širokých vrstev českého obyvatelstva.

Klikova vzpomínka na Matouška je laděna omluvně a jako př́telova obhajoba, a je tak svým způsobem pozdní odpovědí na řadu negativních hlasů, které se na adresu někdejšího člena výboru NS ozvaly bezprostředně po válce, a to i od velmi dobře informovaných osob. Jedním z prvních, kdo odmítl Matouškovo zařazení mezi novodobé národní hrdiny, byl v listopadu 1945 historik a archiváŕ Jan Slavík (1885-1975), jenž shrnul: „Ani majestát smrti nemůže smazat, že Matoušek jednal, jak vzdělaný Čech jednati neměl. Mezi mučedniky české věci patří tím méně. “47 $\mathrm{O}$ dva roky později zasáhl takto do probíhající diskuse o devíti zavražděných 17. listopadu 1939 týdeník Kulturní politika, v němž se konstatovalo: „Byli stoupenci onoho buržoasního nacionalismu, onoho kramářského ,zaplat pánbůh za fašismus ', které třídní sympatie táhlo $k$ dohodě s Mussolinim a Hitlerem, s nimiž je sjednocovala nenávist proti socialismu, proti Sovětskému svazu a proti demokratickému Španělsku (...) Vpravdě to byli lidé, kteři na odboj ani nepomyslili a věřili v možnost legální národní práce v nedemokratickém, totalitním a rasovém Národním souručenstvi (...) Nedělali odboj, ale stali se jeho symbolem. 48 Je třeba připomenout, že redakce obnoveného ČČH, jejímž členem byl i Klik, reagovala na tyto hlasy decentním zveřejněním petice francouzským historikủm, kterou sepsal Matoušek společně s Karlem Stloukalem (1887-1957) a B. Mendlem v září 1938 a do níž údajně právě Matoušek vložil varování, „aby přes české hory střežcí s Rýnem bezpeči Francie, vpadl s Vaším souhlasem nepřitel, který preses Prahu miř́i na Pařriž“ 49

V návaznosti na vzpomínku na J. Matouška Klik připomíná rovněž osobu jeho matky, Magdaleny Matouškové (1881-1948). Vyjadřuje obdiv k její hrdé a zásadové povaze, díky níž se po synově smrti rozhodla neochvějně obhajovat a připomínat jeho odkaz, a to nejen za války, ale i po ní. Jako velkou satisfakci pro Matouškovu matku Klik hodnotí ve své vzpomínce slavnostní akt, k němuž došlo 17. listopadu 1947 v ruzyňských kasárnách. Během něho připomněli oficiální zástupci československé vlády v čele s ministrem národní obrany armádním generálem Ludvíkem Svobodou (1895-1979) osm let staré události. Ministr vnitra Václav Nosek (1892-1955) poté předal jménem vlády rodinám pozůstalým po zavražděných pamětní odznaky druhého národního odboje in memoriam. ${ }^{50}$ Relativně podřadné ocenění, kterého se Matouškovi a jeho druhům dostalo v listopadu 1947, mohlo být interpretováno jako oficiální odmítnutí dobových útoků na ně. Pro Matouškovu rodinu a jeho přátele tudíž mělo v daném okamžiku mnohem větší význam nežli Československý válečný kř́žž 1939, který jim byl udělen in memoriam již tři roky předtím (v říjnu 1945), tedy ještě před rozprouděním diskuse o jejich možné kolaboraci. ${ }^{51}$ Slavnostní akt v ruzyn̆-

$46 \mathrm{~K}$ informacím, jakým způsobem se o Matouškově smrti dovídal ve svém exilu historik O. Odložilík, viz M. ŠTEMBERKovÁ, Josef Matoušek, s. 45-46.

47 Jan Stavík, Jaroslav Papoušek a Josef Matoušek, Národní osvobození 16/145, 1945, 3. 11., s. 1.

48 V. BěHouneK, Tragický osud, Kulturní politika 3/10, 1947-1948, 21. 11. 1947, s. 1.

49 Karel StLouKal, Dokument, С̌ČH 47 (b. č.), 1946, s. 151-155.

50 Při této prríležitosti byla odhalena pamětní deska připomínající, že na tomto místě byl zastřelen 17. listopadu 1939 Josef Matoušek a dalších osm představitelů studentského života. Viz Náplň dnešního 17. listopadu spočivá v zajištěni míru, Rudé právo 27/268, 1947, 18. 11., s. 1.

51 Srov. Osobni věstnik Ministerstva národni obrany 1945, č. 42 (20. 10.), s. 1. 
ských kasárnách ze 17. listopadu 1947 je jedinou událostí, k níž se Klik ve své vzpomínce opakovaně vrací, protože ji zřejmě, jak se lze domnívat, do jisté míry chápal i jako svou osobní satisfakci.

Vzpomínka připomíná také vytrvalou snahu Matouškovy matky vyhledávat s pomocí historiků z řad synových někdejších přátel veškeré podklady a svědectví o životě a díle jejího syna. Připomeňme, že dokumenty, které se jí takto podařilo shromáždit, představují dnes podstatnou část její písemné pozůstalosti. ${ }^{52} \mathrm{Z}$ této bohaté dokumentace se ovšem neodhodlala publikovat téměř nic, co by přibližovalo dospělá léta jejího syna. Svou po válce publikovanou vzpomínku věnovala pouze okamžiku synova narozenín ${ }^{53}$ a svou knihu vzpomínek, vydanou v roce 1948, ${ }^{54}$ ukončila dokonce chronologicky ještě před jeho narozením. Synův př́tel a její spolupracovník při práci na knize Leodegar Wenzel (1906-1981) to komentoval takto: „Snad později dodá k ní maminka Matouškova několik kapitol vzpomínek z dětství i pozdějš́ho období životního osudu synova. Zatím zjitřená bolest vzpomínky bránila častějším a podrobnějš́m zmínkám o něm. "55 Jinak zůstaly její vzpomínkové texty na syna jako už dospělého muže nevydány, a sice s výjimkou drobného svědectví o jeho zatčení 17. listopadu 1939.56

Třetí osobností, které je věnována Klikova vzpomínka, je v té době čtyřiadvacetiletý J. Weinert, pražský rodák, absolvent bohemistiky a germanistiky na Filozofické fakultě UK a tou dobou již středoškolský učitel na vícero pražských školách, naposledy na reálném gymnáziu v Praze XIV. ${ }^{57}$ Od roku 1936 se angažoval v nacionalisticky orientovaném studentském hnutí a zastával v něm řadu vedoucích míst; $\mathrm{z}$ tohoto titulu se pravidelně stýkal i s Klikem jakožto funkcionářem institucí zajišt'ujících studentům sociální pomoc a zdravotní péči. Klikovo ocenění jeho osobnosti je dosvědčeno i odjinud. Mělo jít o člověka s enormně rozvinutým sociálním cítěním, smyslem pro povinnost a tou dobou už poněkud anachronickým pojetím vlastenčení $\mathrm{v}$ duchu 19. století. ${ }^{58} \mathrm{~V}$ září 1939 byl jmenován předsedou Svazu českého studentstva v Praze, což byla jedna ze dvou oblastních složek (druhá sídlila v Brně) Národního svazu českého studentstva, jenž se stal organizační složkou NS. Pražský svaz sdružoval všechny fakultní spolky v Praze, ve kterých bylo nařízeno povinné členství pro všechny studenty. ${ }^{59} \mathrm{Na}$ schůzi výboru tohoto svazu, kterou sám svolal, byl v jeho sídle v Hopfenštokově ulici (dnes Navrátilova, Praha 1) společně s dalšími 16. listopadu asi v 21:30 hod. zatčen a záhy zařazen mezi ty, kteří byli nazítř́ v ruzyňských kasárnách popraveni.

Konečně další osobností, kterou nám tato vzpomínka zpřítomňuje, je samozřejmě Klik sám. Nabízí nám popis řady svých subjektivních zážitků a pocitů, a to nejen tak, jak se mu

52 ANM Praha, f. Matoušková Marie Magdalena (Matouškovi 2), zejména kart. 3.

53 Magdalena Matoušková, Osud je milostiv v naplnění mé velké touhy, Pod Zvičinou 2/3, 1947, 14. 11. 1947, s. 46-48; tamtéž, 2/4, 19. 12. 1947, s. 64 (tento text byl spolu s textem J. Klepla v roce 1947 vydán i samostatně - viz pozn. 42).

54 Magdalena MatoušKovÁ, Nezhoji všechno čas, Praha 1948.

55 Viz Leodegar Wenzel, Nezhojí všechno čas..., in: M. Matoušková, Nezhojí, s. 284-286, zde s. 285.

56 K tomuto zjištění dospěla Jarmila PešKovÁ, Matouškovi 2 - Marie Magdalena Matoušková (1881-1948). Inventár archivního fondu, Praha 1999, s. VI-VII.

57 K J. Weinertovi blíže T. PASÁk, 17. listopad 1939, s. 31, 75-76, 81, 87-89, 103, 196-107 a 112-114, a také J. TOMEš, Devět zapomenutých, s. 20-31.

58 Viz T. PAsÁk, 17. listopad 1939, s. 106-107.

59 K poměrně složité vnitřní struktuře této nové studentské organizace viz sám Jan WEINERT, O organisaci českého studentstva, Národní listy 79/251, 1939, 15. 9., s. 2. 
v paměti uchovaly s mnohaletým odstupem, ale i tak, jak si prál, aby o nich byl informován pro nás blíže neurčitelný recipient v první polovině 60 . let 20 . století. Aniž by to byl primární záměr, vzpomínka nám tak dovoluje nahlédnout i do některých tehdejších autorových motivačních postojü. A asi se nebudeme př́liš mýlit, když konstatujeme, že šlo o postoje príznačné nejen pro samotného Klika, ale spolu s ním i pro značnou část intelektuální scény v období druhé republiky a počínajícího protektorátu. Tyto postoje bychom mohli obecněji charakterizovat takto:

- Snaha nepropadat panice a přes všechnu nepřehlednost a nevypočitatelnost okolního děni zajištovat pravidelnou činnost těch aktivit, které jsou považovány z hlediska udržováni společenské, kulturni a vzdělanostni kontinuity za důležité. To můžeme v př́padě J. Klika jako historika a jako činovníka HK vidět na jeho snaze zajišt'ovat přípravu a vydávání ČČ H, jakmile to situace jen trochu dovolovala. Připomeňme i jeho starostlivost o osudy knihovny Hlávkovy koleje - tedy další relativně významné a tradiční vzdělávací instituce per se, jejižz provoz podporoval již v předcházejících letech. ${ }^{60}$

- Snaha dobrovolnou a vstřícnou spoluprací s okupantským režimem si na něm vymoci, aby nebránil obhajování či posilováni českého národního života. Tato v českých politických i intelektuálních elitách oné doby značně rozšiřená iluze byla více příznačná pro Klikova př́tele J. Matouška, nicméně ve svém vzpomínkovém textu se Klik sám přiznává, že ani jemu nebyla cizí: „Nutno ovšem podotknout, že tehdy ještě jsme podléhali naivni víre, že výbor Národního souručenství bude míti nějakou pravomoc." Klik přitom ještě v této době netušil, že $\mathrm{v}$ nadcházejících letech protektorátu bude jeho vztah $\mathrm{k}$ nacistické moci stále více služebnější, takže se po válce z kroků, které pro ni nuceně konal, bude muset obhajovat neboli v dobovém poválečném žargonu „očišt'ovat“. .61

- Snaha symbolickým vyjadřováním nesouhlasu s okupačním režimem udržovat osobní integritu. V předkládané vzpomínce se Klik stává účastníkem symbolického nesouhlasu vždy jako loajální člen širšího grémia, jehož je členem, konkrétně správního výboru Hlávkových kolejí. Je to právě toto grémium, které se ve významné pozici podílí na Opletalově pražském pohřbu a den poté přijímá usnesení, označující ho za „,mučedníka okupačního režimu“; nevystupuje tedy proti okupantské moci otevřeně jako studenti, ale prostřednictvím symbolických gest a aktů. Josef Klik nepatřil k osobnostem, které se později zapojily do hnutí odporu či odboje, a tak počínaje ranním probuzením dne 17. listopadu 1939 byl u něj tento postoj téměř beze zbytku vytlačen postojem hodně protikladným.

- Snaha předcházet perzekuci ze strany nacistického režimu odstraněním jakýchkoli možných známek odporu a neloajality. Ve vzpomínce J. Klika můžeme tento motivační postoj sledovat, kdykoli líćí, jak se hned od 17. listopadu horečně snažil o likvidaci kompromitujících písemností umístěných jednak v budově Hlávkových kolejí, jednak v zabraných prostorách HK na Filozofické fakultě UK. ${ }^{62}$

60 Viz např. XXXVII. výroční zpráva, s. 16.

61 Srov. JiroušEK, Josef Klik, s. 60-61.

62 Jednalo se především o poschovávané protinacistické a prokomunistické tiskoviny. 
Konečně je třeba připomenout, že při podnikání těchto kroků musel Klik cítit přímé existenciální ohrožení, doprovázené vyčerpávajícím stresem. ${ }^{63}$ Nebyl totiž jen vzdáleným pozorovatelem, ale rázné zásahy nacistické moci se děly v jeho bezprostřední blízkosti: Budova Hlávkovy koleje, v níž se nalézal ještě 16. listopadu 1939 po desáté hodině večerní, byla o pár hodin později přepadena a bylo z ní odvlečeno velké množství osob včetně Klikova následovníka ve funkci ředitele koleje; jeho dosavadní pracoviště, na něž pravidelně docházel, tedy sídlo HK a redakce ČČH na Filozofické fakultě, bylo trvale znepřístupněno i s celou svou cennou a po mnoho let budovanou infrastrukturou. A tři osoby, které důvěrně znal a se kterými se pravidelně stýkal, zemřely v průběhu několika málo listopadových dnů v důsledku tvrdého útoku nacistické moci...

\section{Edice}

\section{Josef Klik: Sedmnáctý listopad 1939}

Dne [11.] listopadu 1939 zemřel v Praze medik Jan Opletal. ${ }^{64}$ Přes usilovnou lékařskou péči podlehl zranění, které utrpěl při protinacistických demonstracích dne 28 . října. ${ }^{65} \mathrm{Jan}$ Opletal byl chovancem Hlávkových kolejí. ${ }^{66}$ Věděl jsem o něm mnoho ještě dříve, než jsem ho poznal osobně; jako referent o přijímání do koleje jsem důkladně pročítal jeho žádost, nebot' jsem byl na něho upozorněn i zvláštním přípisem ředitelstvím jeho gymnasia. Opletal studoval v Litovli, odkud bylo v Hlávkových kolejích více studentů; litovelští dokonce založili pro ně zvláštní stipendium (,založené místo“) a ředitel gymnasia již před projednáváním nových žádostí nás upozorňoval, koho bychom měli z Litovle přijmout. ${ }^{67} \mathrm{~A}$ tak se přimlouval i za Opletala.

Blíže jsem jej poznal, když se stal sociálním referentem studentské samosprávy; tehdy jsem s ním často jako sociální referent i jako ředitel koleje spolupracoval při vypracování návrhů na přijímání nových kolejáků i při udílení stipendií kolejních i stipendií ministerstva školství. Bledý Opletal byl málomluvný, ale velmi seriosní a na poměrně mladý věk opravdově až úzkostlivě svědomitý. Jako chudý student měl opravdové sociální cítění a úzkostlivě dbal, aby stipendia byla rozdělována co nejspravedlivěji. Rád jsem s ním pracoval a ve většině případů jsme se bez obtíží shodli. V koleji byl pokládán za sociálního demokrata; teprve asi 1961 jsem zvěděl od profesora Sosny, ${ }^{68}$ že tam pracoval v komunistické skupině.

Smrt Opletalova mne ovšem velmi bolestně překvapila. Jeho pohřeb se konal za veliké účasti studentů i vysokoškolských učitelů. ${ }^{69}$ Za Správní výbor Hlávkových kolejí jsme polo-

63 Ke zmínce o nervovém zhroucení v listopadu 1939, kdy na radu lékaře odešel z některých funkcí, viz SOkA Jindřichův Hradec, f. Josef Klik, kart. 1, Obhajoba, s. 6.

$64 \mathrm{~K}$ jeho osobě blíže v úvodní části.

65 K demonstracím 28. ř́jna 1939 přehledně T. PASÁK, 17. listopad 1939, s. 37-58.

66 Jeho památku připomíná pamětní deska umístěná na zdi budovy Hlávkovy koleje, Jenštejnská 1, Praha 2.

67 Ředitelem litovelského reálného gymnázia byl v letech 1918-1938 Josef Fürst (1878-1955), př́rodovědec, který se věnoval kromě jiného výzkumu moravských krasových útvarů.

68 V originále je napsáno „prof. Smoly“, jméno je pak přeškrtnuto a ručně opraveno na „prof. Sosny“. K jeho osobě srov. pozn. 38.

69 Pražská tryzna za J. Opletala se konala před transportem rakve k uložení na hřbitově v Náklu u Litovle 15. listopadu 1939 dopoledne v kapli Hlávkova patologického ústavu na Albertově. 
žili věnec..$^{70}$ Po pohřbu došlo k novým protinacistickým demonstracím. ${ }^{71} \mathrm{~V}$ den pohřbu ${ }^{72} \mathrm{se}$ náhodou konala pozdě odpoledne schůze správního výboru kolejí, svolaná ovšem již dřive a podle tehdejších předpisů hlášená policejnímu úřadu. ${ }^{73}$ Schůze byla ovšem pod dojmem Opletalovy smrti. Předseda správního výboru profesor Ing. Dr. O. Quadrát ${ }^{74}$ vzpomněl zesnulého a označil jej za mučedníka okupačního režimu; jeho památka byla uctěna povstáním. Správní výbor pak jednal o tom, jak trvale uctít Opletalovu památku a jednomyslně se usnesl reservovat okamžitě určitou částku na jeho pomník. Zástupci studentstva přítomní na schůzi však prohlásili, že studentská samospráva se rozhodla postavit pomník sama a že studenti sebrali mezi sebou již určitou částku peněz na tento účel. Vděčně jsme kvitovali tento podnět a dohodli se, že budeme uvažovat o jiné formě uctění Opletalovy památky. O tom všem psal tajemník správního výboru doc. Dr. Václav Hovorka ${ }^{75}$ zápis jako o každém jiném bodu jednání.

Další část schůze pak jednala o hospodářských otázkách koleje. Bylo jich mnoho (v souvislosti s vázaným hospodářstvím) a schůze se protahovala. Kolem desáté hodiny večer přišel do koleje $\mathrm{k}$ vrátnému policista a dotazoval se, kdy asi schůze skončí. Věc nám byla nápadná, ale protože všechny schůze musily být tehdy hlášeny, domnívali jsme se, že jde o běžnou policejní evidenci, a nevyvozovali z toho dalekosáhlé závěry. Nacisté však byli již připraveni k obsazení koleje a nechtěli patrně tam vniknout před koncem schůze. Po skončení jednání jsme šli společně do restaurace na večeři a zdrželi se dlouho.

Druhého dne časně ráno nás vzbudila moje př́buzná paní Balaszyová, ${ }^{76}$ která bydlila $\mathrm{v}$ domě vedle koleje, a sdělovala mi, že za noci byla kolej obsazena a studenti i s ředitelem Ing. Václavem Weiserem ${ }^{77}$ odvlečeni; vyslovovala obavy, že budou zatýkáni i členové správního výboru, a vybízela mne $\mathrm{k}$ útěku. Přirozeně jsem byl těmito zprávami velmi roz-

70 Vlastního aktu v kapli, který proběhl mezi 9:30 a 9:40 hod. se podle policejních pokynů zúčastnil jen úzký okruh osob. Za Hlávkovu kolej byla přítomna delegace studentů, člen správního výboru Spolku Hlávkovy koleje profesor ČVUT, matematik František Kadeřávek (1885-1961) a ředitel Hlávkovy koleje V. Weiser. Pro stovky dalších přítomných se tak slavnostním aktem stal až smuteční průvod, při němž byla rakev studenty Hlávkových kolejí vynesena z kaple a naložena do pohřebního automobilu. Při této příležitosti studenti nesli i věnce; věnec Hlávkovy koleje byl sestaven z bílých a červených růží a nesl stuhy v národních barvách. Blíže srov. T. PAsÁK, 17. listopad 1939, s. 69-70. Matematik František Kadeřávek (1885-1961) byl od roku 1920 řádným profesorem deskriptivní geometrie na ČVUT v Praze a roku 1945 se stal i jejím rektorem. Blíže srov. Josef Tomeš, Český biografický slovník XX. století (dále ČBS), I-III, Praha 1999, zde sv. II, s. 16.

71 Události 15. listopadu 1939 přehledně shrnuje T. PASÁK, 17. listopad 1939, s. 69-80.

72 Zřjejmě má být „V den po pohřbu“. Z obsahu vzpomínky vyplývá, že schůze Správního výboru se konala až 16. listopadu 1939, což dosvědčují i jiné prameny. Srov. F. KROPÁč - V. LoudA, Persekuce českého studentstva, s. 66; T. PAsÁk, 17. listopad 1939, s. 80, pozn. 43.

73 Správní výbor se po valné hromadě z června 1939 skládal z těchto osob: Otakar Quadrat (předseda), Ludvík Ambrož (zástupce), Arnošt Brambořík (jednatel), František Kadeřávek (pokladník), Matěj Jelínek, Josef Jeřábek, Josef Klik, Josef Lerch, Jaromír Matouš, František Praus, František Roubík, Bohumil Sochr, Emil Svoboda, Emanuel Šlechta a August Žáček. Viz J. PokornÝ, Odkaz Josefa Hlávky, s. 150.

74 Profesor Vysoké školy chemicko-technologického inženýrství ČVUT Otakar Quadrat (1886-1965) byl dlouholetým předsedou správního výboru Hlávkovy studentské koleje. K jeho osobě J. TomEš, ČBS III, s. 11.

75 Analytický chemik a překladatel Václav Hovorka (1900-1960) byl od roku 1933 docentem na Vysoké škole chemicko-technologického inženýrství ČVUT. Od roku 1927 až do uzavření vysokých škol byl tajemníkem Spolku Hlávkovy studentské koleje českých vysokých škol pražských a jednatelem spolku bývalých chovanců této instituce. Po válce (1945) se stal profesorem Vysoké školy chemicko-technologické a členem-korespondentem ČSAV. Srov. František ČůTA, Člen korespondent ČSAV Václav Hovorka (23. IV. 1900-24. V. 1960), Věstník Československé akademie věd 69, 1960, s. 473-476; J. TOMEš, ČBS I, s. 509.

76 Př́ibuzenský vztah k J. Klikovi bohužel není z kontextu zřejmý.

77 K osobě V. Weisera srov. pozn. 23. 
rušen. Netušil jsem, že jsou obsazeny i jiné koleje a vysoké školy, a měl jsem za to, že tvrdý úder je namířen pouze proti koleji Hlávkově, kde bydlil Opletal, a to proto, že zástupci studentů i ředitel koleje se musili před Opletalovým pohřbem zavázat, že nebude porušen klid. ${ }^{78}$ Protože došlo k bouř́m, mínil jsem, je trestána kolej...

Odešel jsem do školy a teprve tam jsem zvěděl, že jsou obsazeny i jiné koleje a budovy vysokých škol. A nemýlím-li se, teprve odpoledne byly vylepeny vyhlášky oznamující uzavření vysokých škol na tři léta a popravu devíti studentských předákủ. ${ }^{79}$ Jména jejich zatím jsem neznal, a proto jsem netušil, že budou mezi nimi i moji dva přátelé.

Ve škole mne čekalo dopoledne ještě jiné překvapení. V deset hodin přišel do školy můj bývalý žák, tajemník Historického klubu Otava, ${ }^{80}$ a sděloval mi, že nebyl vpuštěn do Klubu, jehož místnosti byly v budově filosofické fakulty na Smetanově náměstí. ${ }^{81}$ Teprve nyní jsem si uvědomil, že obsazením vysokých škol jsou zabrány i klubovní místnosti! To bylo velmi trapné zjiššění; věděl jsem, že v klubovních místnostech si studenti od jara 1939 ukrývali a vyměňovali protinacistické letáky a ukládali některé v knihovně. Neměl jsem jistoty, zda tak činili i v poslední době a jsou-li v klubovní knihovně ony tisky dosud. Otava mi dal rozpačitě zápornou odpověd', ale z jeho rozčilení jsem pochopil, že ví o věci více, než ríká. A tak se stupňovaly obavy, co bude dále.

Mezi dnem přicházely nové a nové zprávy o zabírání jednotlivých fakultních budov i kolejí i o řádění Němců v těchto budovách. Bylo sdělováno, že jsou zatýkáni i studenti mimo koleje, a že proto mnozí studenti opouštějí Prahu; šíriily a potvrzovaly se zvěsti, že student, který není právě doma, když má být zatčen, není dále stíhán a gestapo jde jinam, nebot' prý nejde o určité osoby, nýbrž o to, aby byl zatčen určený počet vysokoškoláků... Odtud houfné útěky studentů z Prahy. Protože prý v kolejích byli zatčeni převážně nejchudší studenti, jsou prý podle seznamů mimo kolej zavíráni hlavně studenti z řad vyšších úředníků a živnostníků, aby tak byli postiženi studenti ze všech sociálních složek. Nevím, bylo-li tomu tak, ale bývalí studenti z Vančurova gymnasia, ${ }^{82}$ kteří byli zatčení, byli vskutku synové vyšších úrredníků. I v následujících dnech se potvrzovalo, že studenti, kteří nebyli doma, př̌šlo-li gestapo, unikli zatčení. Asi za tři nebo čtyři dni zatýkání podle kolujících zpráv ustalo. Studenti byli odvlečeni do koncentračních táborů.

Ještě 17. listopadu jsem na cestě ze školy potkal profesora techniky Ing. Dr. Fr. Kaderávka ${ }^{83}$, který byl také členem správního výboru Hlávkových kolejí. Bydlil na Karlově náměstí, tedy blízko kolejí, a měl podrobné zprávy o jejich obsazení. Sám očekával př́padné sankce i proti vysokoškolským učitelům a pracovníkům v studentském hnutí. Byl však

78 K zárukám, že při pražském pohřbu J. Opletala bude zachován klid, které 14. listopadu poskytl úředním místům předseda samosprávy M. Martischnig, srov. T. PAsák, 17. listopad 1939, s. 65 a 67, zde pozn. 41.

79 Vyhláška byla vyhotovena paralelně v němčině a češtině, byla datována 17. listopadu 1939 a byla opatřena podpisem ř́šského protektora K. v. Neuratha, který ovšem po válce autenticitu svého podpisu rozhodně popíral s odkazem na pobyt v Berlíně. V černobílém přetisku viz Jaroslav ČvančARA, Někomu život, někomu smrt. Československý odboj a nacistická okupační moc 1939-1941, Praha 2002, s. 89. Originální exemplář je uložen ve sbírkách AUK.

80 Absolvent reálného gymnázia na Smíchově Alois Otava, který maturoval v roce 1932, byl žákem J. Klika, jenž byl jeho třídním učitelem. Poté studoval teologii na UK v Praze a působil jako tajemník HK. Srov. Památník k padesátému výroči založení Stát. čsl. reálného gymnasia v Praze XVI-Smíchově, Praha 1934, s. 83.

81 Dnes to je Náměstí Jana Palacha v Praze 1.

82 Jde o Státní československé reálné gymnasium Dr. Jindřicha Vančury v Praze XVI (na Smíchově), které od sklonku roku 1938 zredukovalo svůj název na Státní reálné gymnasium v Praze XVI (dnešní Gymnázium Na Zatlance).

83 K jeho osobě srov. pozn. 70. 
neobyčejně klidný; nebál se př́ipadného zatčení a zdůrazňoval, že přináší-li oběti mládež, tím spíše ji musí nésti i její učitelé a vedoucí. Povzbudil mne svým klidem, ale přece jen nezbavil rozechvění nad osudem tolika studentů a nad tvrdostí německého úderu; pochopitelně se hlásila i nejistota $\mathrm{z}$ vlastního osudu. Toto rozechvění ještě vzrostlo, když mi při náhodném setkání sdělil Dr. Kristen, ${ }^{84}$ že mezi popravenými je i Dr. Matoušek. ${ }^{85}$

Dlouho jsem nechtěl zprávě věřit. Docent všeobecných dějin Dr. Josef Matoušek byl syn bývalého realistického a pak národně demokratického politika, který býval před Mnichovem i ministrem. ${ }^{86}$ Matoušek byl žákem Šusty, ${ }^{87}$ který do něho vkládal velké naděje. Zabýval se vedle historie i politikou, redigoval některé časopisy a patřil $\mathrm{k}$ těm publicistům, kteří v době před Mnichovem hlásali nutnost dorozumění s Němci. Po německé okupaci se netajil tím, že se mýlil, domníval-li se, že je možný s Němci smír, a trpce si stěžoval, že část našeho obyvatelstva 15 . března 1939 zvědavě přihlížela pohybům nacistických vojenských sborů v Praze. Živě si vzpomínám, jak mi asi za dva dni nato vykládal, jak jinak se zachovali Francouzi za pruské okupace 1870/71, kdy Prušáci pochodovali liduprázdnými ulicemi a kdy Francouzi stáhli i rolety, aby nemusili hledět na potupné obsazeníl ${ }^{88}$

Když bylo v březnu 1939 vytvořeno Národní souručenství, stal se Matoušek členem výboru, a nemýlím-li se, byl mu svěřen i referát péče o mládež nebo aspoň členství v nějaké komisi toho druhu ${ }^{89}$ Matoušek se začal mnoho zajímat o sociální péči studentskou. Nutno ovšem podotknout, že tehdy ještě jsme podléhali naivní víre, že výbor Národního souručenství bude míti nějakou pravomoc a bude tudíž moci i v sociální péči studentské vyvinout účinnou iniciativu. Poněvadž jsem pracoval v studentské péči nejen jako člen a sociální referent Správního výboru Hlávkových kolejí, nýbrž i jako předseda podpůrného odboru Sboru sociální péče o vysokoškolské studentstvo ${ }^{90} \mathrm{i}$ jako člen výboru Studentského zdravotního ústavu, ${ }^{91}$ obracel se Matoušek vícekrát na mne o informace a také na podzim 1939 jsem s ním o studentských otázkách několikráte jednal a smluvil jsem mu pak schůzku asi na 14. nebo 15 . listopadu s profesorem Weinertem ${ }^{92}$ a seznámil ho s ním.

84 Archivár̆ Zdeněk H. M. Kristen (1902-1967) tehdy působil v Archivu země České v Praze a věnoval se mj. editování diplomatických dokumentů. Srov. J. Hoffmanová - J. PražÁková, Biografický slovník archivárùu, s. 348; J. Tomeš, ČBS II, s. 181-182.

$85 \mathrm{~K}$ osobě J. Matouška blíže v úvodní části.

86 Právník, národohospodář a politik Josef Matoušek st. (1876-1945) byl poslancem Revolučního národního shromáždění (1918-1920) a Národního shromáždění ČSR (1920-1935), později senátorem (1935-1939). V letech 1929-1934 byl ministrem průmyslu, obchodu a živnosti v druhé vládě F. Udržala a první vládě J. Malypetra za Čs. národní demokracii. K jeho osobě srov. J. TOMEš, ČBS II, s. 359.

87 Profesor všeobecných dějin na FF UK a v letech 1939-1945 prezident České akademie věd a umění Josef Šusta (1874-1945) patřil k našim předním historikům. K jeho osobě srov. Jiří LaCH, Josef Šusta 1874-1945. A history of a life, a life in history, Olomouc 2003.

88 Klikem tlumočený Matouškův výklad odpovídá jednomu z historických mýtů, který se traduje k prusko-francouzské válce a následné pruské okupaci 1870/1871.

89 Výbor NS jakožto jediné ze strany nacistů tolerované politické organizace byl jmenován prezidentem E. Háchou 23. března 1939; Matoušek byl od začátku jedním z jeho členů a působil v řadě jeho výborů (programový, kulturní, soustřed'ovací, organizační a správní). Byl i zástupcem vedoucího NS ve Velké Praze. Vysokoškolskou a studentskou problematikou se Matoušek zaobíral jako prezidiální zpravodaj Kulturní rady a jako takový byl zván i k poradám o školství ministrem J. Kaprasem. Srov. Program školské práce. Zástupci Kulturní rady u ministra školství, Národní listy 79/196, 1939, 29. 7., s. 2.

90 Ke Sboru sociální péče o vysokoškolské studentstvo viz pozn. 25 v úvodní části.

91 Ke Studentskému zdravotnímu ústavu viz pozn. 26 v úvodní části.

92 Ke středoškolskému profesorovi a studentskému předáku J. Weinertovi viz blíže v úvodním textu. Klikovu vzpomínku, jak seznámil Weinerta s Matouškem v polovině listopadu 1939, bude asi nutné poněkud korigovat, nebot’ oba muži se spolu zúčastnili audience představitelů českého studentstva u ministra školství a národní 
Weinerta jsem poznal již jako studenta, který pracoval ve Sboru pro sociální péči o vysokoškolské studentstvo i v jiných studentských organisacích hlavně sociálního charakteru. ${ }^{93}$ Vynikal neobyčejnou pracovitostí a svědomitostí a snažil se o krajní spravedlnost v rozdílení studentských stipendií a všech výhod. Byl společensky obratný; měl velmi pěkné, snad až př́lilš zdvořilé vystupování, př́i čemž zvlášt' nápadná byla úcta k mínění jiných a takt, s nímž polemizoval. Nesouhlasil-li s něčím, bojoval za své mínění pevně, ale velmi taktně. Sociální péči studentské věnoval každou volnou chvíli i za svých studií i tehdy, když již vyučoval na pražské střední škole.

Na schůzku Matouškovu s Weinertem jsem si vzpomněl při svých úvahách o osudu Matouška a za několik minut nato jsem zvěděl, že i Weinert patří k devíti předákům studentstva, kteří byli popraveni. A tak možná stáli vedle sebe osudového rána 17. listopadu dva moji přátelé, které jsem krátce před tím vzájemně seznámil... Tak se mi od té doby stále vynořovali pospolu a tak jsem na ně také vzpomínal 17. listopadu 1947, když jsem byl př́itomen na nádvoří ruzyňských kasáren odhalení pamětní desky popraveným a odevzdání vyznamenání jejich pozůstalým...94

Věru bylo příliš mnoho bolesti v onen neblahý sedmnáctý listopad a stále se k ní družila i obava, co bude dále. Poslechl jsem rady přátel a po dva dni nespal doma, ale poznal jsem zbytečnost tohoto počínání. O spánku ovšem nelze vlastně mluvit, ostatně jistě v tyto dni velmi málo lidí v Praze mohlo vůbec spát, protože nové podrobnosti o brutalitě vůči studentům přinášely nová a nová rozčilování...

Úřední zpráva nemluvila o tom, kde byla poprava vykonána; teprve později byly potvrzeny pověsti o ruzyňských kasárnách. Něco světla do průběhu událostí vnesli i někteří nejmladší studenti, kteří byli v kolejích zatčeni, odvezeni, ale pak propuštěni. ${ }^{95}$ Byl mezi nimi i můj krajan Josef Poslušný, ${ }^{96}$ který bydlil v Masarykově koleji. Když byl propuštěn, přišel k nám, líčil brutalitu německých vojáků a ukazoval modřiny po ranách, které dostal. Radil se, co má dělat. Podle toho, co jsem všude slyšel, jsem mu mohl jen doporučit, aby odjel co nejdříve domů a opatřil si nějaké zaměstnání! Učinil tak. V Deštné jej přijali jako výpomocného úředníka na obecní úřad. Za čas nebyl spokojen se svým postavením, domáhal se zlepšení, a když nebylo možno mu vyhovět - přestoupil k Němcům a strhl s sebou i oba rodiče, ač otec, můj spolužák z obecné školy, neznal ani slova německy! Tak malicherné osobní důvody vedly slabé povahy až k národní zradě... Němci pak ustanovili Poslušného (psal se pak Posluschny) učitelem kdesi na Jindřichohradecku a později poslali na vojnu. Po revoluci 1945 se chtěl vrátit, ale když mu obec odepřela pobyt, zůstal někde v západním Německu.

V těžkých listopadových dnech mne ovšem velmi zajímal i osud ředitele kolejí Ing. Weisera, který se stal ředitelem, když jsem já na tuto funkci resignoval (v létě 1937). ${ }^{97}$ Brzy jsem se dozvěděl, že se mu podařilo dostat se na svobodu s nějakou skupinou, která byla propuštěna, že však okamžitě jej Němci znovu hledali i v koleji i jinde. Nepolapili jej!

osvěty J. Kaprase již 20. 9. 1939. Srov. Zástupci českého studentstva u ministra školství a národní osvěty, Národní listy 78/259, 1939, 23. 9., s. 2.

93 Ke Sboru viz pozn. 25 v úvodní části.

94 K slavnostnímu aktu v ruzyňské věznici 17. 11. 1947 viz v úvodu, respektive v pozn. 50.

95 Z asi 1850 osob zatčených 17. listopadu 1939 byli týž den propuštěni cizinci, členové fašistických a antisemitských organizací a asi 600 studentů mladších 20 let. Srov. T. PAsÁk, 17. listopad 1939, s. 101.

96 K osudům Josefa Poslušného/Posluschneho zatím nejsou známy další podrobnosti.

${ }^{97}$ Ke Klikově rezignaci na místo ředitele Hlávkovy koleje viz blíže v úvodu k této edici. 
Weiser zmizel a prchl za hranice. Je pochopitelné, že jsem mnoho dumal o tom, jaký asi by byl můj osud, kdybych byl zůstal i nadále ředitelem koleje! Také předseda studentské samosprávy Martischnigg i někteří jiní kolejáci prchli za hranice!98 Byli totiž po Opletalově pohřbu v Praze na Litovelsku, kam byl Opletal převezen; když se dozvěděli, co se děje, již se nevrátili a odešli za hranice.

V koleji byli ubytováni př́slušníci německých ozbrojených sborů - tuším SS. Tajemník koleje doc. Dr. Hovorka se obrátil na jejich velitele s tím, že jako úředník má v koleji své soukromé věci, a žádal, aby si je mohl odnésti. Velitel - byl prý to v civilu také vysokoškolský učitel - k našemu překvapení svolil. Hovorka použil návštěvy v koleji i k tomu, aby odnesl i zápisy o schůzi, v níž bylo usneseno uctít památku Opletalovu. Tento zápis pak dobře uschoval.

A jaký byl další osud kolejí? Němci brzy plenili i kolejní inventáŕ; jak jsme od vrátného, který tam zůstal, zvěděli, odváželi odtud i zásoby ložního prádla, jídelního náčiní apod. ${ }^{99}$ Později kolej opustili a v budově byl umístěn nějaký úřad. ${ }^{100}$ Bohatá kolejní knihovna, která vznikla dary jednotlivců i korporací, měla být odvezena do sběru! Podařilo se získat knihkupce a antikváře Andrého, ${ }^{101}$ který ji koupil, když mu z ministerstva školství Dr. Roubík ${ }^{102}$ a německý knihovník Mucha ${ }^{103}$ slíbili, že ji úřady od něho odeberou později.

Za několik dní po 17. listopadu jsem byl pozván na návštěvu k paní Matouškové, matce popraveného historika. ${ }^{104}$ Věděla, že jsem s ním těsně před jeho smrtí byl ve stycích, a chtěla vědět všechny podrobnosti, každé slovo, které pronesl - sbírala je u všech jeho přátel. Byla podivuhodně klidná a několikrát podotkla, že není čas na smutek, nýbrž na př́ípravu odvety. „Musíme si zachovat zdraví a nervy, abychom se mohli mstít,“ pravila. Vedla si i v pozdějších dobách stejně důstojně; nikdy nebyla skleslá, zoufalá, vždy hrdá a klidná. „Není čas na pláčc““ ‘ríkala, „na to oni čekaji, a nesmi se jim ukázat slabost a musí se chystat odveta. "Vždy, když jsem ji viděl, měl jsem představu hrdé antické matky, jak jsem si ji vytvořil v studentských dobách na jindřichohradeckém gymnasiu.

98 Student Maxmilian Martischnig (1912-1984) bydlel podobně jako Opletal na Hlávkově koleji a v roce 1938 se stal předsedou tamní studentské samosprávy (Jan Opletal byl jeho zástupcem). Organizoval Opletalův pohřeb a počátkem roku 1940 se mu podařilo odejít za hranice. Studoval pak medicínu v Oxfordu a sloužil v čs. exilové armádě. Z emigrace se již do vlasti nevrátil. K odchodům studentů v této době blíže Karel A. MACHÁČEK, Útěk do Anglie = Escape to England, Praha 2003.

99 K plenění inventáře Hlávkovy koleje viz J. Pokorný, Odkaz Josefa Hlávky, s. 155.

100 Od počátku roku 1941 v budově sídlil český Zemský úřad, viz J. PoKornÝ, Odkaz Josefa Hlávky, s. 155.

${ }^{101}$ Firma „Antiquariat K. André“ sídlila tehdy v paláci Praha (Havířská 3, Praha 1); jednalo se o tradiční a nejznámější pražský antikvariát, proslulý svými dražebními katalogy starých tisků.

102 Historik, archivář a Klikův krajan František Roubík (1890-1974) působil v letech 1939-1948 jako referent Ministerstva školství a národní osvěty a v letech 1939-1952 byl zároveň i ředitelem Státního historického ústavu. K jeho osobě srov. J. Hoffmannová - J. PražÁkovÁ, Biografický slovník archivárù, s. 545-546; J. Tomeš, ČBS III, s. 57.

103 Klik zde uvádí toto př́imení nesprávně. Jednalo se o Antona Mouchu (1882-1945), knihovníka a dlouholetého ředitele knihovny Německé vysoké školy technické v Praze. Působil rovněž jako inspektor MŠANO pro německé knihovny v českých zemích, respektive profesor i ředitel Státní školy knihovnické. K jeho podílu na zachraňování významných knihovních celků v Praze srov. Robert LuFT, Das Bibliothekwesen in Böhmen und Mähren während der nationalsozialistischen Herrschaft, Bohemia 30/2, 1989, s. 295-342, k podílu na zachraňování knihovny Hlávkovy koleje konkrétně s. 334.

104 Matouškova matka Magdalena (1881-1948), roz. Jínová se narodila v Bořkově u Semil v rodině Jana Jíny, továrníka v Prostřední Nové Vsi. V únoru 1905 se provdala v Lázních Bělohrad za právníka Josefa Matouška, tehdy c. k. soudce. Z manželství vedle syna Josefa vzešla v roce 1909 i dcera Eva, provdaná Schubertová. 
I později se mne vyptávala na každou maličkost ze života svého Pepánka, na každý jeho výrok, názor. Vše chtěla vědět do nejmenších podrobností a důtklivě žádala, abych jí třeba písemně sdělil, kdybych si na něco vzpomněl. Trpěla patrně strašně, vždyt' ve svém synu viděla vskutku nadějného vědce, ale uměla se přemoci a nikdy nedala najevo svůj bol. Neměl jsem slov obdivu pro její sílu, statečnost a sebezapření, zvláště uvážil-li jsem, že dosud žila celkem bezstarostným životem v klidné, dobře situované domácnosti. Nosila po synovi stále smutek, a když úřady naléhaly, aby jej odložila, dokonce pohrozily, odpověděla: „Syna jste mi zavraždili, co mi ještě můžete udělat!“ V elektrické dráze jí důstojník nabídl místo. Odmítla se slovy: „Zavraždili jste mi syna, tímto si mne nesmíríte. "Posilovala druhé, povzbuzovala k vytrvalosti. Soustředila se na sbírání všech podrobností ze života synova; jeho přátelé Dr. Klepl ${ }^{105}$ a L. Wenzl ${ }^{106}$ jí pomáhali.

Když se po květnové revoluci vyskytly hlasy, že docent Matoušek byl popraven nedopatřením a že nepatřil k odbojovým pracovníkům, ${ }^{107}$ soustředila své úsilí $\mathrm{k}$ tomu, aby jej rehabilitovala a ukázala, že byl ilegálně činný. Nezkrušila ji ani smrt manžela, jenž zemřel za měsíc po revoluci, 5. 6. 1945. ${ }^{108}$ Naopak, jakoby cítila ještě větší zodpovědnost za rehabilitaci Matouškova jména. Vyvíjela v té věci stejnou energii jako dříve v šíření nenávisti k Němcům. Tehdy mi napsala: „Historie odstupem času všechno osvětlí, ríkával můj hoch, jenže matce pětašedesátileté se nechce čekat, až si historie vzpomene, musí se snažit to ,osvětleni' uspíšit!" Při tom ještě nalezla dosti sil, aby napsala pozoruhodné paměti, hlavně ze svého mládí, jimž dala přiléhavý nadpis Nezhojí všechno čas. ${ }^{109}$

Krok za krokem zjednávala uznání svému stanovisku. Dočkala se. Dne 17. listopadu 1947 byl její den. Tehdy přijímala na nádvoří ruzyňských kasáren vyznamenání pro svého mrtvého syna z rukou ministrů vnitra a národní obrany a byla přítomna odhalení pamětní desky popraveným předákům studentstva, na níž Matouškovo jméno bylo na čelném místě. ${ }^{110}$ Tam jsem ji viděl naposledy, stále stejně hrdou a důstojnou. A tehdy jsem slyšel naposled i její hlas, když pohnutě, ale pevně děkovala zástupcům vlády jménem všech pozůstalých po popravených. Tím vyvrcholila a vlastně již skončila její životní dráha. Záhy se přihlásila zákeřná choroba, tuberkulosa, které patrně čelila svým obrovským životním elánem. Byl jsem doopravdy hluboce dojat, když jsem se jako pacient táborské nemocnice dozvěděl, že dne 7. září 1948 tato statečná žena zemřela.

Vzpomínkou na hrdou a statečnou českou ženu nekončí mé vzpomínky na sedmnáctý listopad! Jak jsem se již zmínil, byly s budovou filosofické fakulty zabrány i místnosti Historického klubu. Byla to jedna místnost administrativní, a pak rozsáhlá knihovna o více

105 Historik a archiváŕ Jan Klepl (1907-1965) působil v Archivu země České a v Archivu pro dějiny průmyslu, obchodu a technické práce. Josefu Matouškovi věnoval poválečnou vzpomínku, jak je blíže uvedeno v úvodní části. K jeho osobě srov. J. HoffmanovÁ - J. PražÁKovÁ, Biografický slovník archivářu, s. 312-313.

106 Klik zde uvádí toto př́ijmení v nesprávné podobě. Leodegar Wenzel (1906-1981) byl středoškolský profesor dějepisu a zeměpisu, který působil na různých českých školách. Napomáhal M. Matouškové při sepisování její knihy vzpomínek. K tomu blíže v úvodní části.

107 Jako jeden z prvních tento názor zřejmě vyslovil v listopadu 1945 historik J. Slavík, jak bylo uvedeno v úvodní části.

108 Josef Matoušek st. ve skutečnosti zemřel již o den dříve, než J. Klik uvádí, tzn. 4. 6. 1945. Viz jeho úmrtní oznámení v ANM Praha, f. J. Matoušek st. (Matouškovi 3), kart. 1.

109 Ke knize viz úvodní část.

110 Zmiňovaným vyznamenáním byl pamětní odznak druhého národního odboje in memoriam; k jeho udělení viz úvodní část. 
než 20000 svazcích; mimo to byly na několika místech uloženy zásoby publikací Klubem vydaných i starších ročníků Českého časopisu historického a množství učebnic. Jen část některých nerozebraných publikací i učebnic byla u komisionáře (Družstva knihkupců). ${ }^{111}$ Jen ty byly možno eventuálně expedovat; jinak činnost klubu ustala.

Od zř́zzence fakulty pana Zahrádky jsme se dozvěděli, že knihovna klubovní je naprosto neporušena, jen $\mathrm{v}$ administrativní místnosti prý Němci dělali prohlídky a rozházeli po zemi mnoho listin a papíru. Zahrádka nás ujistil, že ani tam však nyní nikdo nechodí. On také vzal tajně do svého bytu psací stroj klubu a oknem jej večer předal panu Otavovi (Zahrádka bydlil v př́zemí fakultní budovy). Měl přesně zjištěno, kdy německé hlídky, které stále kolem budovy obcházely, jsou na druhé straně, a využil i zatemnění a stroj odevzdal.

Asi v lednu nebo počátkem února 1940 intervenoval Šusta u kteréhosi německého historika (tuším Zatschka) ${ }^{112}$ a dosáhl toho, že jsme si z klubovních místností mohli odnést potřebné úřední knihy, kartotéku a jiné věci potřebné pro běžnou agendu. Tak jsem měl poprvé po 17. listopadu př́ležitost vstoupit do místností klubovních. Hned při vstupu jsem poznal, co vskutku bylo rozházeno po podlaze, jak o tom mluvil Zahrádka. Měl jsem tam veliký koš, ve kterém byla uložena část písemné pozůstalosti profesora Pekaře. ${ }^{113}$ Odvezl jsem ji tam po Pekařově smrti v neurovnaném stavu a po týdny jsem denně srovnával lístek za lístkem, dopis za dopisem. Němci se patrně domnívali, že jsou v koši ilegální tiskopisy, koš obrátili a vše přeházeli, ale nezničili, ani neodnesli. Musil jsem později vše srovnávat znova. Zatím jsem ovšem mohl v rychlosti pouze vše naházet do koše, který jsme odnesli do knihovny.

Ta zůstala bohudík zcela nedotčena; zdá se, že tam okupanti pouze nahlédli a nic nepřehlíželi. Bylo hned patrno, že knihy zůstaly v regálech na svých místech a že ani s jednotlivými kusy nábytku nebylo hýbáno. To bylo vskutku štěstí, jak jsem se přesvědčil v následujících minutách. Šel jsem totiž ke skř́ním, v nichž byly uloženy kartotéční lístky, inventář knihovny apod. Některé zásuvky byly doslova přeplněny protinacistickými letáky, které si tam uložili studentští funkcionáŕi klubu. Mimo to tam bylo několik desítek výtisků časopisu Studkor, ${ }^{114}$ který před léty kolportoval Mirko Bidlas. ${ }^{115}$ Byl také jako student klubovním funkcionářem, udržoval styk s knihovnou i později. Jako student odjel do Sovětského svazu

111 Tím je míněno Obchodní družstvo českých knihkupců, které sídlilo v Knihkupeckém domě ve Vězeňské ulici, dnes Praha 1.

112 Historik Heinz Zatschek (1901-1965) byl profesorem středověkých dějin a pomocných věd historických na Filosofické fakultě pražské Německé univerzity. Během okupace vstoupil do NSDAP a badatelsky se přeorientoval na „Volksforschung“. K jeho úloze na nacifikované Německé Karlově univerzitě srov. Alena MíšKová, Die Deutsche (Karls-) Universität vom Münchener Abkommen bis zum Ende des Zweiten Weltkrieges. Universitätsleitung und Wandel des Professorenkollegiums, Praha 2007, s. 14, 22, 48, 69, 80-81, 95, 98, 104, 109, $112,121,154-156,158,162-163,165,183-184,195,198,201,216,244,248,251-252,325$.

113 Josef Pekař (1870-1937) byl přední český historik a profesor Filozofické fakulty UK. Pekařovu písemnou pozůstalost J. Klik převzal do svého dočasného držení na základě poslední vưle Josefa Pekaře, v níž Klika pověřil úkolem, ,aby srovnal mé papíry a určil, co má býti odevzdáno Museu“ (tj. Národnímu muzeu v Praze) - viz B. JiRoušEK, Josef Klik, s. 42. Viz i Martina NovozÁMSKÁ, Josef Pekař v pozůstalosti Josefa Klika, in: Ivo Navrátil (ed.), Josef Pekař a české dějiny 15.-18. století. Sborník referátů z vědecké konference konané ve dnech 8.-9. dubna 1994 v Turnově a Sedmihorkách, Bystrá nad Jizerou 1994, s. $23-27$.

114 Časopis „Studkor. Zprávy studentské delegace do SSSR“ byl vydáván jako měsíčník od konce roku 1931 studentským odborem Společnosti pro kulturní a hospodářské sbližení s SSSR. Srov. Levicové časopisy na vysokých školách, in: J. Kladiva (ed.), Za lepší budoucnost, s. 324-336.

115 Historik Miroslav Bidlas (1900-1990) se po roce 1945 věnoval československo-sovětským vztahům, později se vrátil k problematice 19 . století. 
a vydal pak několik čísel časopisu Studkor (Studentská korespondence), v nichž propagoval SSSR mezi studenty. Nerozebraný zbytek nákladu pak ponechal v klubovní knihovně, kde tyto výtisky přečkaly i několik týdnů německé okupace.

Byli jsme v tíživé situaci... Věděli jsme, že jde o vzácný historický materiál, ale nemohli jsme jej tam ponechat, nebot' jsme neměli jistoty, že Němci i nadále do knihovny nevkročí. A nemohli jsme jej odnést, nebot' jsme měli výslovně povoleno odvézt jen knihy k úřední agendě, a v budově hlídkovali členové SS. Rozhodli jsme se s Otavou, že to rychle spálíme, nebot' stěhování za asistence nacistických žoldnéřo bylo riskantní! Náš plán se nezdařil; papír nehořel a kamna strašně kouřila, takže dýmu byly plné chodby. Jako zázrakem se objevil pan Zahrádka a rázem věc rozřšsil: dal letáky do košů a postranním výtahem odvezl do kotelny. A my jsme jen již v klubu mohli uvažovat, co by se asi stalo, kdyby Němci byli prohlíželi i knihovnu...

Klub mohl potom zčásti pokračovat ve své činnosti, ovšem velmi omezené; Otava úřadoval ve svém bytě. Připravovali jsme pak nové číslo Českého časopisu historického, které také vyšlo.

Koncem března 1940 jsem byl spěšným dopisem pozván na děkanství filosofické fakulty. Děkan Rypka ${ }^{116}$ nám sdělil, že všechny spolky, které v budově fakulty mají sídlo, mohou všechen svůj majetek vystěhovat, ale musí tak učinit ve velmi krátké době - tuším tří dnů. Nebyla to práce snadná; nákladních aut byl nedostatek; byl konec kvartálu, kdy stěhovací firmy byly zadány. Podařilo se nám jen s obtíží sehnat vozy z venkova. Ale kam s množstvím knih a zásobou skladu? Vzpomněl jsem si na ředitele Zemského archivu Dr. Bedřicha Jenšovského, ${ }^{117}$ který byl také členem výboru Klubu. Sedával jsem s ním v tu dobu obyčejně dvakrát týdně v kavárně Daliborce ${ }^{118}$ a měl jsem př́ležitost poznat jeho pevné, sokolské nesmlouvavé češství, jeho odpor k okupantům a pohrdání jimi, i jeho vzácnou nebojácnost, která ho později stála život! 119

Tušil jsem, že bude ochoten poskytnout Klubu útočiště v budově archivní. Vskutku, když se pak Šusta ihned obrátil na Jenšovského, ten velmi ochotně vyhověl; dovolil, abychom do archivu přestěhovali sklad a uvolnil nám dokonce místnost administrativní. ${ }^{120}$ Protože v budově archivní byl i Archiv pro dějiny průmyslu ${ }^{121}$ a protože se s námi současně tam nastěhoval se svou částí knihovny i profesor Šusta, stal se tak archiv jakýmsi střediskem historické obce; tam jsme se scházeli a v těžkých dobách posilovali!

116 Orientalista Jan Rypka (1886-1968) byl profesorem FF UK a byl zvolen do funkce děkana pro akademický rok 1939/40, po válce v letním semestru 1945 a pro školní rok 1945/46. K jeho osobě srov. J. Tomeš, ČBS III, s. 74.

117 Archiváŕ a historik Bedřich Jenšovský (1889-1942) stál v čele Českého zemského archivu jako jeho ředitel od roku 1933. R. 1942 byl za odbojovou činnost popraven. Srov. Antonín Kostlán, Bedřich Jenšovský, in: Michal V. Šimůnek - Antonín Kostlán (edd.), Biografický slovník obětí nacistické perzekuce z řad vědecké obce v českých zemích 1939-1945, I, (A-K), Praha 2019, s. 251-254.

118 Kavárna Daliborka se nalézala na Hradčanech v Badeniho ulici, pár set metrů od tehdy nové budovy Českého zemského archivu.

119 B. Jenšovský byl v ř́jnu 1941 zatčen gestapem v rámci „Akce Sokol“ a zemřel v koncentračním táboře Osvětim. Srov. A. Kostlán, Bedřich Jenšovský, s. 251-254.

120 Tím se myslí budova Českého zemského archivu (dnes prvního oddělení Národního archivu) v Praze 6 v ulici Milady Horákové 5/133. Budova byla postavena v letech 1929-1933, o její vzhled se zasloužil i architekt J. Fragner. K přestěhování Historického klubu do této budovy viz i Otakar BAUER, Zpráva o činnosti českého zemského archivu za léta 1934-1941, Zprávy Českého zemského archivu 9, 1946, s. 349-350.

121 Je míněn Archiv pro dějiny průmyslu, obchodu a technické práce v Praze, jehož fondy později přešly do dnešního Národního technického muzea (NTM). K němu více Jan KLEPL, Archiv pro dějiny průmyslu, obchodu a technické práce v Praze, Věstník Národního technického muzea 30/2-4, 1950, s. 101-107. 
Činnost klubu byla ovšem velmi omezená, ale nikoli bez významu. V těžkých dobách okupace byla i historická kniha posilou; mohli-li jsme proto uspokojovat zájemce z řad členů i mimo ně půjčováním historických knih, mělo i to jistě tehdy význam. Český časopis historický jsme vydali ještě roku 1940; roku 1941 bylo jeho vydávání zastaveno. ${ }^{122}$

\section{Ediční poznámka}

Podkladem edice se stal autorem ručně opravovaný strojopis textu, který je uložen v Okresním archivu Jindřichův Hradec, fond Kulturně historický archiv (KHA), kart. 81, i. č. 515 , poř. č. 2 .

Tento strojopis obsahuje devět jednostranně popsaných listů formátu A4. Text není datován; dobu jeho vzniku můžeme ohraničit léty 1961 (poslední datum zmiňované v textu) a 1965 (rok Klikova úmrtí). Jméno autora je vepsáno ručně verzálkami v pravém horním rohu prvního listu.

Edice respektuje původní pravopisnou podobu Klikova svědectví, interpunkci a psaní velkých písmen však opravuje podle dnešního úzu. Bylo upraveno i členění textu na odstavce, aby bylo přehlednější a více vyhovovalo vnitřní logice Klikova sdělení. Denní datum Opletalova úmrtí bylo $\mathrm{v}$ originále vynecháno, a je tu proto doplněno $\mathrm{v}$ hranaté závorce. V textu použité zkratky („ČČH““, „prof.“, „pí“ aj.) jsou rozvedeny, psaní akademických titulů jinak necháváme $\mathrm{v}$ původní podobě.

Veškeré vysvětlující či doplňující poznámky vložené do textu edice pocházejí od editorů; jejich účelem je osvětlit zmiňované reálie.

\section{Grantová podpora}

Tento článek vznikl v rámci projektu GAČR 17-27132S.

PhDr. Antonín Kostlán, CSc. Ústav pro soudobé dějiny $A V \check{C} R, v . v . i$. kostlan@seznam.cz

Mgr. Michal V. Šimůnek, Ph.D. Ústav pro soudobé dějiny $A V \check{C} R, v . v . i$. simunekm@centrum.cz

${ }^{122} \mathrm{~K}$ tomuto období ve vývoji ČČH viz Josef KLIK, Vzpomínky na Josefa Šustu z doby okupace, Jihočeský sborník historický 38, 1969, s. 226-237; Jiří ŠPÉT, Po stu letech (K výroči Českého časopisu historického), ČC̆H 93, 1995, s. 13-34, zde s. 13-14. 